\title{
Study on Construction of Cultural Capital among Entrepreneurs
}

\author{
Lei $\mathrm{Xu}$ \\ Ph.D. Student, Jilin University \\ \& School of Marxism, Changchun University of Science and Technology \\ Changchun 130022, China \\ E-mail: xl@cust.edu.cn \\ Shuo Song \\ International Education College, Jilin Agricultural University \\ Changchun 130118, China
}

Received: June 30, 2011 Accepted: July 25, 2011 doi:10.5539/ass.v7n9p203

\begin{abstract}
Culture of entrepreneurs is also a sort of capital, which has a direct effect on development of enterprises in the process of economic operation of enterprises. Construction of cultural capital among entrepreneurs helps to enhance the overall competitive strength of Chinese enterprises in international society and helps to push forward development of the economic society. Due to historical reasons, construction of cultural capital among entrepreneurs in China is, to some extent, weak and should strengthen cultivation from the three aspects of enhancing comprehensive quality of entrepreneurs, their consciousness of obligation and consciousness of innovation at present.
\end{abstract}

Keywords: Culture of entrepreneurs, Cultural capital of entrepreneurs

\section{Connotation of cultural capital among entrepreneurs}

Construction of cultural capital of entrepreneurs is a critical aspect that concerns about how much space an enterprise has in terms of survival and development. Culture of entrepreneurs is directly and closely connected with economic benefit of enterprises. New international and domestic economic backgrounds have proposed brand-new subjects to construction of cultural capital among entrepreneurs in China. Therefore, only if construction of cultural capital among entrepreneurs continues to be updated and escalated fundamentally, can we guarantee that our enterprises increase their competitive strength in the international society and promote orderly, healthy and harmonious development of the society and economy. Culture of entrepreneurs is a sort of peculiar corporate cultural phenomenon and is the integration of cultural quality, innovative capacity, management concept and operation principles of corporate management personnel. Culture of entrepreneurs is also a sort of capital and is the most important non-economic element for economic growth of enterprises, with a function that can't be ignored in economic running.

With development and progress of economics and society, the concept of capital has been continuously extended and enriched and the forms and content of capital are also various, not only including material capital and monetary capital in the simple sense, but also widely extended in meaning as human capital. Culture of entrepreneurs is also a sort of human capital, which runs through the entire operation process of an enterprise, reflects anticipated value in the economic activities of an enterprise and creates more social wealth. Culture of entrepreneurs is an individual cultural phenomenon in the great social and cultural system, and has distinct individualized features. Cultural capital of entrepreneurs is always reflected through particular entrepreneur individuals. Cultural capital of entrepreneurs is crystallization of brainwork of entrepreneurs. In the long term process of growth of entrepreneurs, the accumulation process of their comprehensive capacity ultimately forms the sum of cultural capital of entrepreneurs. Cultural capital of entrepreneurs reflects the personal charm of entrepreneurs. In the mean time, under definite circumstance, value of cultural capital of entrepreneurs is also gradually highlighted with development of individual development. 


\section{An analysis of the current condition of cultural capital construction among entrepreneurs}

On one hand, ever since the reform and opening up in China, quite a lot of state-owned enterprises and private economy have been rapidly developed. However, as a result of historical reasons, cultural construction among entrepreneurs has not formed an effective management mode. The prominent characteristics of culture among entrepreneurs are that, the operation and management ideas of modern enterprises lag behind, the overall knowledge and cultural quality of entrepreneurs is not high and their consciousness of conservation is quite strong, which all seriously constrains the overall development level of the team of entrepreneurs. It should be mentioned, entrepreneurs in quite a large number of large and medium-sized state-owned enterprises obviously have the phenomenon of weak cultural capital construction in the process of transition of enterprises and in the process of reform. These enterprises not only are lacking in modernized corporate management ideas, but also are unable to adapt to the objective development requirements of modern modernized market economy in terms of property rights reform theory and in other practical activities. In addition, so far as private-owned enterprises, quite a lot of private entrepreneurs have grown up in traditional family enterprises, so many of them haven't received relevant training about professional corporate management and have great difficulty in terms of cultivation of cultural capital among entrepreneurs. However, a batch of farmer entrepreneurs have also emerged among the Chinese farmers who account for a large proportion of population in China in the process of urbanization. As for farmer entrepreneurs, construction of culture among entrepreneurs seems especially urgent.

On the other hand, construction of cultural capital among entrepreneurs in China is far behind the developed countries, such as US and Japan, etc. Ever since the reform and opening up in China, culture of entrepreneurs still has not been widely accepted by the society, and quite a lot of entrepreneurs only start out from profit making of enterprises, but ignore development of culture of entrepreneurs. From the perspective of the entire society, the whole society has, so far, not totally built a great environment that is helpful for construction of cultural capital among entrepreneurs. The issues of rules and regulations on corporate management, reform of state-owned enterprises, incentive system of entrepreneurs and property right system in China have not been fundamentally resolved, which also restrains development of cultural capital among entrepreneurs. Only if entrepreneurs depend on a benign economic running mode on the basis of sufficient development of the market and continuously explore practice, can they form a sort of culture that belongs to entrepreneurs themselves in the process of management of the enterprises. Then, culture of entrepreneurs can be escalated consciously to an invisible capital and ultimately forms cultural capital of entrepreneurs, implanting to each process of corporate management as a sort of soft culture.

\section{Solutions to strengthen construction of cultural capital of entrepreneurs}

\subsection{To enhance comprehensive quality of entrepreneurs}

Fundamentally speaking, construction of cultural capital among entrepreneurs should be based on comprehensive quality of entrepreneurs since it is the necessary condition for construction of cultural capital among entrepreneurs. Comprehensive quality of entrepreneurs includes cultural quality and management quality. Cultural quality includes political quality of entrepreneurs, namely, grasp of the national policy and strategy as well as the overall economic running condition of the international society. Psychological quality refers to emergency of entrepreneurs and grasp of corporate risk consciousness. Cultural education quality refers to degree of higher education among entrepreneurs. Management quality mainly refers to the professional skills of entrepreneurs. It is true that entrepreneurs are unable to be proficient with all affairs, but modern enterprises have to have knowledge in market, finance, capital running, personnel management and capital risk management, etc. As the pioneers of state-owned pillar industry, entrepreneurs of state-owned enterprises should combine the reality of China, strengthen more the modernized management and operation ideas, change concepts and make state-owned enterprises adapt to the development rules of modernized market economy. As the pioneer of Haier Group, Zhang Ruimin not only is familiar with professional knowledge in electrical appliance, but is also proficient in Chinese traditional culture. It is exactly owing to the excellent entrepreneur that the brand of Haier had a value of 63.7 billion RMB Yuan as early as 2007 and has been ranked the first among all electronic and information enterprises in China. Likewise, as for private entrepreneurs, since they are affected by the management mode of traditional family enterprises, they should more walk out the traditional family management, break through old concepts and out-dated modes and lead the enterprises to walk towards a modernized management path.

\subsection{To enhance consciousness of responsibility among entrepreneurs}

Implementation of scientific outlook on development and the times requirement to construct a harmonious socialist society both have proposed new demands on enterprises to perform their social responsibilities and on 
quality of entrepreneurs. Boosting development of China economy clamors for joined efforts of entrepreneurs. Formation of culture of entrepreneurs should be established in the long term development goal of enterprises, the country and the nation. The era clamors for excellent culture of entrepreneurs. This requires formation of entrepreneurs' culture to further take into consideration responsibilities in terms of operation with credit, environmental protection and maintenance of social public welfare. Meanwhile, this calls for higher expectations on entrepreneurs in terms of the consciousness of rule by law and moral accomplishment, consciousness of environmental protection and operation principle, spiritual state and team leadership, social participation and social influences, etc. Construction of cultural capital among entrepreneurs ought to let entrepreneurs' culture inherit the traditional culture of Chinese nation. Culture of entrepreneurs can't break away from the culture of the entire nation, and it is necessarily part of the national culture. dating back to the traditional culture of China, we can find that the theory of Confucian entrepreneurs has been existing early on. The so-called Confucian entrepreneurs refer to those who undertake commercial activities, especially entrepreneurs. Although what they participate in is a sort of economic activity, they do not work exclusively for profit and worship the golden calf. These people have strong sense of social responsibility and have higher cultural level and rational cultural structure. Especially, they have profound comprehension in the traditional culture of China. Adam Smith, Founder of economics, also explain that entrepreneurs are not merely "economic men", and are simultaneous "social men". The two should be unified. In his works, he also doesn't exclude role of ethics in the market economy. At a new era, construction of culture capital among entrepreneurs still needs to vigorously strengthen the consciousness of social responsibility of entrepreneurs. Entrepreneurs should carefully carry out the policies and strategies of the country and show concern for the society, since "blood of morality flows on entrepreneurs". After the 5.12 Wenchuan earthquake, it was discovered that quite a large number of entrepreneurs took an initiative in lending a helping hand and participated in the action of earthquake relief work. When the country and the society needs them, they can give returns to the society and assume due social responsibilities.

With requirement of social development in China, new demands of the times are proposed on culture capital of entrepreneurs. It is also an important aspect to develop circular economy in the future for entrepreneurs to enhance the consciousness of environmental responsibility from the perspective of management. Today, quite a lot of countries all over the world are positively exploring the mode to develop circular economy. Generally speaking, the circular economy advocates an economic development mode that is harmonious with the environment, increases the maximum utilization rate of resources, persists in the $3 \mathrm{R}$ principles (reduction, reuse and recycle), protects ecological environment and pushes forward sustainable development of economic society. Vigorous development of the circular economy is a significant strategy for development of economy and the society. It is definitely pointed out in "Central Party Committee's suggestions on the 12th five-year-plan for national economy and social development" that was approved in the Fifth Plenary Session of the Seventeenth Central Committee, we should vigorously develop circular economy, speed up construction of resource conserving and environmentally friendly society, and enhance ecological and civilization level, for which entrepreneurs ought to take the responsibility of environmental protection. Development of enterprises should comply with harmonious development of the society and the environment and with the overall requirement of development of the circular economy. Of course, entrepreneurs ought to have good environmental protection consciousness, conserve resources, reduce pollution and develop a circular economy mode of low consumption and less discharge.

However, we can also find out some entrepreneurs are lacking in social responsibility and have also brought about negative influences to the society. The dairy products incident which has received most attention is an obvious example. Usually, behaviors of entrepreneurs may exert a decisive influence upon development of enterprises. Only if entrepreneurs operate an enterprise with honesty and credit as well as lofty personality charm, can they acquire enormous economic benefits.

\subsection{To enhance consciousness of innovation among entrepreneurs}

Consciousness of innovation is the central constituent element for culture capital of entrepreneurs. A general survey of undertaking processes of all successful entrepreneurs all over the world, it can be found that the idea of innovation always accompanies. The Economist, Schumpeter, proposed for the first time in his "The Theory of Economic Development" the idea that "innovation" is the "source power" for development of capitalistic economy. He defined innovation as entrepreneurship and escalated competition mechanism to innovation mechanism. Peter Drucker, the contemporary US management master, ever said, innovation is an instrument held by entrepreneurs and they resort to this instrument to pioneer all changes in the society to opportunities to perform different undertakings or services. In the Top 500 Global corporations in "Fortune", there are only 15 enterprises in the mainland China. In the more and more fierce global competition, such foreign brands as Coca 
Cola and Mcdonald's are glutting around us. What we are in need of are entrepreneurs with the consciousness of innovation to build an international brand of China, to create patent of the enterprises and to really realize rejuvenating the country through science and technology.

The consciousness of innovation among entrepreneurs is in proportion to the benefits of the enterprises. Only more innovative ideas are presented in the cultural value deposits of entrepreneurs, can the enterprises have greater developmental potential. The consciousness of innovation of entrepreneurs mainly includes the following four aspects. In the first place, innovation which originates from products and service. As for industrial enterprises, only if they target at definite consumption groups and pioneer characteristic products with excellent quality, can they obtain a tiny space in competition in the market. Nowadays, choice of consumers varies greatly and how to acquire favor of customers for the products from the multitude of commodities should not only rest with products with high quality, but should also take into consideration the assorted subsequent service which is an important element. As invisible capital, the service of products offered by the enterprises can also add to more jetton for development of enterprises in the future. In the second place, innovation which originates from marketing channels. With popularization of information and network technology, the traditional marketing channels can no longer fit with the marketing level of enterprises. Such new marketing ideas as network marketing and TV marketing have silently mapped into the vision of people. Under the new marketing mode, enterprises have to develop various marketing competitions according to features of their enterprises and their products so as to push forward their products to the market up to the hilt. In the third place, innovation originating from organization and management. Innovative capacity of entrepreneurs is also reflected in their organization and management of the entire enterprises, such as innovation of human resource management, innovation of institution management and budget of the finance, etc. There is nothing eternal in the world and different stages of development require entrepreneurs to make a sensible decision and to really and thoroughly integrate the idea of innovation into organization and management of the enterprises. In the fourth place, innovation should also avoid risks. Innovation co-exists with risks. Innovation always means certain risks, which requires entrepreneurs to be good at effectively controlling risks in practice before they carry out a decision-making of innovation.

\section{References}

Joseph Schumpeter. (1990). The Theory of Economic Development. The Commercial Press.

Liao, Xiaoping. (1999). Charm of Modern Confucian Entrepreneurs. Haichao Publishing House.

Peter Drucker. (1987). Entrepreneurs and Innovation. Nanning: Guangxi People's Publishing House.

Wang, Liyan, Yin, Chunyan \& Li, Weigang. (1997). An Analysis of Survey on Entrepreneurs' Environmental Concept and Environmental Management. Economic Science.

Yuan, Zhiyong. (2003). Innovation Behavior and Innovation Obstacle. Shanghai: Joint Publishing Company.

Zhang, Weiying. (1995). Entrepreneurs of Enterprises --- Contract Theory. Shanghai: Joint Publishing Company. 